\title{
Chemical polishing of samples obtained by selective laser melting from titanium alloy Ti6Al4V
}

\author{
Andrey V. Balyakin ${ }^{1 *}$, Aleksei N. Shvetcov ${ }^{1}$, and Evgeny I. Zhuchenko ${ }^{1}$ \\ ${ }^{1}$ Samara National Research University, Samara, Russian Federation
}

\begin{abstract}
The paper discusses a method of chemical polishing of Ti6Al4V samples and presents the results of our study. The samples were produced by selective laser melting, which is an increasingly popular method of producing thin-walled, geometrically complex products. The document analyzes how polishing with solutions featuring a varying content of hydrofluoric and nitric acids affects the etching rate and alters the superficial roughness of the samples in both the longitudinal and the transverse directions. We have thus formulated the recommendations on the optimum composition and concentration of such acidic solutions for polishing Ti6Al4V products made by selective laser melting.
\end{abstract}

High operating properties of titanium-alloy parts, including their good corrosion resistance and biocompatibility, make these alloys popular in various industries [1, 2]. Today, titanium alloys are widely used in aerospace, mechanical engineering, medicine, and other industries. They are used for making high-precision thin-walled and geometrically complex parts sometimes containing inner channels and cavities [3, 4].

The rapidly developing additive technologies can produce any product layer-by-layer if there is a digital 3D model for this product $[5,6]$. Such processes are sometimes referred to as "growth" due to their gradual nature. Depending on the technology, it's either a down-top or top-down production process, which affects the properties of the object produced.

Selective laser melting, or SLM, is an additive manufacturing technology which forms a three-dimensional product by pre-programmed laser consequential melting of powder layers. SLM features high material utilization ratio and minimizes post-machining stock removal, which makes SLM a preferred technology for geometrically complex parts, especially when made of titanium alloys. SLM-produced parts are currently too rough, having an $\mathrm{Ra}$ of up to $4.5 \mu \mathrm{m}$ and an $\mathrm{Rz}$ of up to $32 \mu \mathrm{m}$, which is too much for parts used in aerospace, mechanical engineering, or medicine.

Post-machining of geometrically complex thin-walled parts produced by SLM is a very relevant question, as it comes to machining the inner surfaces and removing non-smelted powder particles from the surface. Mechanical machining is not always efficient enough due to the geometric complexity, thin walls, and low removable-stock reserves. Besides, as titanium allows have low thermal conductivity, the mechanical machining of thin parts

\footnotetext{
* Corresponding author: balaykinav@ssau.ru
} 
might result in structural and phase changes inn the material, which generate tensile residual stresses and result in the warpage of parts [7,8].

This paper discusses chemical polishing of Ti6Al4V parts. The main reagent used for the chemical polishing of titanium and titanium alloys is hydrofluoric acid (HF) [9]. When polishing this titanium alloy, the reaction is as follows:

$$
\mathrm{Ti}+3 \mathrm{HF} \rightarrow \mathrm{TiF}_{3}+\frac{3}{2} \mathrm{H}_{2} \uparrow
$$

When polishing titanium or its alloys using HF, it produces titanium trifluoride and hydrogen gas. Despite the fact that HF erodes titanium as such, it has some negative effects. First of all, hydrogen gas produced by the reaction is a flammable and explosive product, presenting a fire hazard. Second, HF quickly reduces its concentration in a solution, which requires regular replenishment to keep the acid content sufficiently high. Third, the polishing rate is quite low. Finally, the polished surface might still be non-satisfactory [10, 11]. To eliminate some of these drawbacks, nitric acid is added to the HF solution. The etching reaction is then written as:

$$
\mathrm{Ti}+6 \mathrm{HF}+4 \mathrm{HNO}_{3} \rightarrow \mathrm{H}_{2} \mathrm{TiF}_{6}+4 \mathrm{NO}_{2} \uparrow+4 \mathrm{H}_{2} \mathrm{O}
$$

As can be seen from the reaction equation, titanium etching produces hexafluorotitanic acid, nitrogen dioxide, and water. Using this solution stabilizes HF, prevents the production of hydrogen, and even accelerates the etching at specific nitric acid concentrations.

We've run a series of field experiments to study how using varying-content HF- and nitric-acid solutions would affect the chemical polishing of titanium alloys, namely the etching rate and the surface quality [12].

Ti6Al4V was the titanium alloy of our choice. This is a titanium-aluminum-vanadium alloy that has a dual-phase structure $(\alpha+\beta)$ and is hardened by heat treatment, including quenching and aging that makes it stronger though somewhat less ductile [13, 14].

Table 1. Chemical composition of Ti6Al4V, \%

\begin{tabular}{|c|c|c|c|c|c|c|c|c|c|c|}
\hline \multirow{2}{*}{$\mathbf{T i}$} & $\mathbf{A l}$ & $\mathbf{V}$ & $\mathbf{C}$ & $\mathbf{F e}$ & $\mathbf{S i}$ & $\mathbf{Z r}$ & $\mathbf{O}_{\mathbf{2}}$ & $\mathbf{N}_{\mathbf{2}}$ & $\mathbf{H}_{\mathbf{2}}$ & $\begin{array}{c}\text { Other impurities } \\
\text { total }\end{array}$ \\
\cline { 4 - 10 } & & & \multicolumn{8}{|c|}{ not exceeding } \\
\hline Base & $\begin{array}{c}5.3- \\
6.8\end{array}$ & $\begin{array}{c}3.5- \\
5.3\end{array}$ & 0.10 & 0.60 & 0.10 & 0.30 & 0.20 & 0.05 & 0.015 & 0.30 \\
\hline
\end{tabular}

Samples were produced by selective laser melting on an SLM 280 machine [15] and had the following dimensions: $35 \mathrm{~mm}$ in length, $10 \mathrm{~mm}$ in width, and $2 \mathrm{~mm}$ thick. These were the production parameters: laser radiation power $\mathrm{P}=275 \mathrm{~W}$, scanning rate $\mathrm{S}=805 \mathrm{~mm} / \mathrm{s}$. Before polishing, all the samples were checked for weight and surface roughness in longitudinal and transverse directions. The etching conditions were the same for each sample under analysis. We used $50 \mathrm{ml}$ of solution at $25^{\circ} \mathrm{C}$. All the solutions had been produced by weight percentage. For etching, we used polypropylene containers.

Tables 2 to 4 present the initial parameters and the chemical polishing results for $3 \%$, $5 \%$ and $10 \%$ HF solutions; the tables also show how these solutions affected the polishing rate.

Tables 5 and 6 present the longitudinal and transverse surface roughness data for these specific solutions presented in tables 2 to 4 . 
Table 2. Initial parameters and chemical polishing results for various 3\% HF solutions

\begin{tabular}{|c|c|c|c|c|c|c|c|}
\hline $\begin{array}{c}\text { Chemical } \\
\text { polishing } \\
\text { solution }\end{array}$ & $\begin{array}{c}\text { Sample } \\
\text { thickness } \\
\text { before } \\
\text { etching, } \\
\text { mm }\end{array}$ & $\begin{array}{c}\text { Sample } \\
\text { thickness } \\
\text { after } \\
\text { etching, } \\
\text { mm }\end{array}$ & $\begin{array}{c}\text { Average } \\
\text { loss } \\
\text { of } \\
\text { thickness, } \\
\text { mm }\end{array}$ & $\begin{array}{c}\text { Rate } \\
\text { of } \\
\text { etching, } \\
\text { mm/min }\end{array}$ & $\begin{array}{c}\text { Sample } \\
\text { weight } \\
\text { before } \\
\text { etching, } \\
\text { g }\end{array}$ & $\begin{array}{c}\text { Sample } \\
\text { weight } \\
\text { after } \\
\text { etching, } \\
\text { g }\end{array}$ & $\begin{array}{c}\text { Etching } \\
\text { time, } \\
\text { min }\end{array}$ \\
\hline $3 \% \mathrm{HF}$ & 2.14 & 2.06 & 0.08 & 0.005 & 2.9399 & 2.8561 & 15 \\
\hline $\begin{array}{c}3 \% \mathrm{HF}+3 \% \\
\mathrm{HNO}\end{array}$ & 2.12 & 2.08 & 0.04 & 0.003 & 2.5321 & 2.4679 & 15 \\
\hline $\begin{array}{c}3 \% \mathrm{HF}+6 \% \\
\mathrm{HNO}\end{array}$ & 2.15 & 2.06 & 0.09 & 0.006 & 2.6495 & 2.5834 & 15 \\
\hline $\begin{array}{c}3 \% \mathrm{HF}+10 \% \\
\mathrm{HNO}\end{array}$ & 2.13 & 2.08 & 0.05 & 0.003 & 2.8357 & 2.7695 & 15 \\
\hline $\begin{array}{c}3 \% \mathrm{HF}+15 \% \\
\mathrm{HNO}\end{array}$ & 2.15 & 2.09 & 0.06 & 0.004 & 2.5432 & 2.4848 & 15 \\
\hline $\begin{array}{c}3 \% \mathrm{HF}+20 \% \\
\mathrm{HNO}\end{array}$ & 2.15 & 2.07 & 0.08 & 0.005 & 2.6423 & 2.5602 & 15 \\
\hline
\end{tabular}

Table 3. Initial parameters and chemical polishing results for various $5 \% \mathrm{HF}$ solutions

\begin{tabular}{|c|c|c|c|c|c|c|c|}
\hline $\begin{array}{c}\text { Chemical } \\
\text { polishing } \\
\text { solution }\end{array}$ & $\begin{array}{c}\text { Sample } \\
\text { thickness } \\
\text { before } \\
\text { etching, } \\
\text { mm }\end{array}$ & $\begin{array}{c}\text { Sample } \\
\text { thickness } \\
\text { after } \\
\text { etching, } \\
\text { mm }\end{array}$ & $\begin{array}{l}\text { Average } \\
\text { loss } \\
\text { of } \\
\text { thickness, } \\
\text { mm }\end{array}$ & $\begin{array}{c}\text { Rate } \\
\text { of } \\
\text { etching, } \\
\text { mm/min }\end{array}$ & $\begin{array}{c}\text { Sample } \\
\text { weight } \\
\text { before } \\
\text { etching, } \\
\text { g }\end{array}$ & $\begin{array}{c}\text { Sample } \\
\text { weight } \\
\text { after } \\
\text { etching, g }\end{array}$ & $\begin{array}{c}\text { Etching } \\
\text { time, } \\
\text { min }\end{array}$ \\
\hline $5 \% \mathrm{HF}$ & 2.19 & 2.07 & 0.12 & 0.008 & 2.9141 & 2.7726 & 15 \\
\hline $\begin{array}{c}5 \% \mathrm{HF}+3 \% \\
\mathrm{HNO}\end{array}$ & 2.18 & 2.10 & 0.08 & 0.005 & 2.9990 & 2.9061 & 15 \\
\hline $\begin{array}{c}5 \% \mathrm{HF}+6 \% \\
\mathrm{HNO}\end{array}$ & 2.15 & 2.07 & 0.08 & 0.005 & 2.9509 & 2.8176 & 15 \\
\hline $\begin{array}{c}5 \% \mathrm{HF}+10 \% \\
\mathrm{HNO}\end{array}$ & 2.07 & 2.02 & 0.05 & 0.003 & 2.2521 & 2.1037 & 15 \\
\hline $\begin{array}{c}5 \% \mathrm{HF}+15 \% \\
\mathrm{HNO}\end{array}$ & 2.05 & 2.02 & 0.03 & 0.002 & 2.0485 & 1.9074 & 15 \\
\hline $\begin{array}{c}5 \% \mathrm{HF}+20 \% \\
\mathrm{HNO}_{3}\end{array}$ & 2.06 & 2.02 & 0.04 & 0.006 & 2.3538 & 2.1896 & 7 \\
\hline
\end{tabular}

Table 4. Initial parameters and chemical polishing results for various $5 \% \mathrm{HF}$ solutions

\begin{tabular}{|c|c|c|c|c|c|c|c|}
\hline $\begin{array}{l}\text { Chemical } \\
\text { polishing } \\
\text { solution }\end{array}$ & $\begin{array}{c}\text { Sample } \\
\text { thickness } \\
\text { before } \\
\text { etching, } \\
\text { mm }\end{array}$ & $\begin{array}{c}\text { Sample } \\
\text { thickness } \\
\text { after } \\
\text { etching, } \\
\text { mm }\end{array}$ & $\begin{array}{c}\text { Average } \\
\text { loss } \\
\text { of } \\
\text { thickness, } \\
\text { mm }\end{array}$ & $\begin{array}{c}\text { Rate } \\
\text { of } \\
\text { etching, } \\
\text { mm/min }\end{array}$ & $\begin{array}{c}\text { Sample } \\
\text { weight } \\
\text { before } \\
\text { etching, } \\
\text { g }\end{array}$ & $\begin{array}{c}\text { Sample } \\
\text { weight } \\
\text { after } \\
\text { etching, } \\
\text { g }\end{array}$ & $\begin{array}{c}\text { Etching } \\
\text { time, } \\
\text { min }\end{array}$ \\
\hline $10 \% \mathrm{HF}$ & 2.15 & 2.00 & 0.15 & 0.021 & 3.0660 & 2.8681 & 7 \\
\hline $\begin{array}{c}10 \% \mathrm{HF}+3 \% \\
\mathrm{HNO}_{3} \\
\end{array}$ & 2.15 & 2.00 & 0.15 & 0.021 & 2.9074 & 2.7084 & 7 \\
\hline $\begin{array}{c}10 \% \mathrm{HF}+6 \% \\
\mathrm{HNO}_{3} \\
\end{array}$ & 2.10 & 1.95 & 0.15 & 0.021 & 3.2482 & 2.8574 & 7 \\
\hline $\begin{array}{c}10 \% \mathrm{HF}+10 \% \\
\mathrm{HNO}_{3}\end{array}$ & 2.12 & 2.00 & 0.12 & 0.024 & 3.5643 & 3.333 & 5 \\
\hline $\begin{array}{c}10 \% \mathrm{HF}+15 \% \\
\mathrm{HNO}_{3} \\
\end{array}$ & 2.14 & 2.01 & 0.13 & 0.026 & 3.6154 & 3.4718 & 5 \\
\hline $\begin{array}{c}10 \% \mathrm{HF}+20 \% \\
\mathrm{HNO}_{3}\end{array}$ & 2.10 & 1.95 & 0.15 & 0.030 & 3.3727 & 2.9954 & 5 \\
\hline
\end{tabular}


Table 5. Surface roughness before and after chemical polishing with various $3 \%$ HF solutions

\begin{tabular}{|c|c|c|c|}
\hline \multirow{2}{*}{ Chemical polishing solution } & \multicolumn{2}{|c|}{ Sample surface roughness, $\boldsymbol{\mu m}$} & \multirow{2}{*}{ Surface alteration ratio } \\
\cline { 2 - 3 } & Before polishing & After polishing & \\
\hline $3 \% \mathrm{HF}$ & $\mathrm{Ra}=4.36$ & $\mathrm{Ra}=3.97$ & 1.10 \\
\hline $3 \% \mathrm{HF}+3 \% \mathrm{HNO}_{3}$ & $\mathrm{Ra}=4.36$ & $\mathrm{Ra}=3.35$ & 1.30 \\
\hline $3 \% \mathrm{HF}+6 \% \mathrm{HNO}_{3}$ & $\mathrm{Ra}=4.24$ & $\mathrm{Ra}=3.06$ & 1.38 \\
\hline $3 \% \mathrm{HF}+10 \% \mathrm{HNO}_{3}$ & $\mathrm{Ra}=4.26$ & $\mathrm{Ra}=3.96$ & 1.07 \\
\hline $3 \% \mathrm{HF}+15 \% \mathrm{HNO}_{3}$ & $\mathrm{Ra}=3.93$ & $\mathrm{Ra}=4.21$ & 0.93 \\
\hline $3 \% \mathrm{HF}+20 \% \mathrm{HNO}_{3}$ & $\mathrm{Ra}=4.18$ & $\mathrm{Ra}=3.42$ & 1.22 \\
\hline
\end{tabular}

Table 6. Surface roughness before and after chemical polishing with various $5 \%$ HF solutions

\begin{tabular}{|c|c|c|c|}
\hline \multirow{2}{*}{$\begin{array}{c}\text { Chemical } \\
\text { polishing solution }\end{array}$} & \multicolumn{2}{|c|}{ Sample surface roughness, $\boldsymbol{\mu m}$} & $\begin{array}{c}\text { Surface } \\
\text { alteration ratio }\end{array}$ \\
\cline { 2 - 3 } & Before polishing & After polishing & \\
\hline $5 \% \mathrm{HF}$ & $\mathrm{Ra}=3.78$ & $\mathrm{Ra}=2.86$ & 1.32 \\
\hline $\begin{array}{c}5 \% \mathrm{HF}+3 \% \\
\mathrm{HNO}_{3}\end{array}$ & $\mathrm{Ra}=3.78$ & $\mathrm{Ra}=2.05$ & 1.84 \\
\hline $\begin{array}{c}5 \% \mathrm{HF}+6 \% \\
\mathrm{HNO}\end{array}$ & $\mathrm{Ra}=3.63$ & $\mathrm{Ra}=2.41$ & 1.50 \\
\hline $\begin{array}{c}5 \% \mathrm{HF}+10 \% \\
\mathrm{HNO}\end{array}$ & $\mathrm{Ra}=6.70$ & $\mathrm{Ra}=4.30$ & 1.56 \\
\hline $\begin{array}{c}5 \% \mathrm{HF}_{3}+15 \% \\
\mathrm{HNO}\end{array}$ & $\mathrm{Ra}=6.70$ & $\mathrm{Ra}=4.19$ & 1.60 \\
\hline $\begin{array}{c}5 \% \mathrm{HF}_{3}+20 \% \\
\mathrm{HNO}\end{array}$ & $\mathrm{Ra}=6.70$ & $\mathrm{Ra}=4.98$ & 1.34 \\
\hline
\end{tabular}

Table 7. Surface roughness before and after chemical polishing with various $10 \% \mathrm{HF}$ solutions

\begin{tabular}{|c|c|c|c|}
\hline \multirow{2}{*}{$\begin{array}{c}\text { Chemical } \\
\text { polishing solution }\end{array}$} & \multicolumn{2}{|c|}{ Sample surface roughness, $\boldsymbol{\mu m}$} & $\begin{array}{c}\text { Surface } \\
\text { alteration ratio }\end{array}$ \\
\cline { 2 - 3 } & Before polishing & After polishing & \\
\hline $10 \% \mathrm{HF}$ & $\mathrm{Ra}=4.27$ & $\mathrm{Ra}=2.39$ & 1.79 \\
\hline $\begin{array}{c}10 \% \mathrm{HF}+3 \% \\
\mathrm{HNO}_{3}\end{array}$ & $\mathrm{Ra}=4.27$ & $\mathrm{Ra}=2.23$ & 1.91 \\
\hline $\begin{array}{c}10 \% \mathrm{HF}+6 \% \\
\mathrm{HNO}\end{array}$ & $\mathrm{Ra}=4.22$ & $\mathrm{Ra}=4.44$ & 0.95 \\
\hline $\begin{array}{c}10 \% \mathrm{HF}+10 \% \\
\mathrm{HNO}_{3}\end{array}$ & $\mathrm{Ra}=3.99$ & $\mathrm{Ra}=1.69$ & 2.36 \\
\hline $\begin{array}{c}10 \% \mathrm{HF}+15 \% \\
\mathrm{HNO}_{3}\end{array}$ & $\mathrm{Ra}=3.99$ & $\mathrm{Ra}=2.15$ & 1.85 \\
\hline $\begin{array}{c}10 \% \mathrm{HF}+20 \% \\
\mathrm{HNO}_{3}\end{array}$ & $\mathrm{Ra}=4.22$ & $\mathrm{Ra}=2.64$ & 1.60 \\
\hline
\end{tabular}

SLM-produced parts have superficial convexities and concavities, the location of which depends on the laser scanning strategy. Chemical polishing solutions affect the surface 
evenly, which is why measuring the surface roughness perpendicularly to the track direction yields different results compared to measuring along the track.

As shown by this study, chemical polishing with a hydrofluoric acid solution is a rather slow process that generates a by-product. The by-product is hydrogen gas. Adding nitric acid to the solution accelerates etching, eliminates hydrogen gas production, and produces a smoother surface. Increasing nitric acid content above ten percent has no significant effect on the etching rate. Besides, higher HF concentrations result in the generation of titanium oxide on the surface; the oxide is white-colored and extremely difficult to remove.

Initial surface roughness and the presence or absence of non-smelted sections do affect the etching rate and the surface roughness of SLM-produced samples polished by a HF$\mathrm{HNO}_{3}$ solution, see Figure 1.

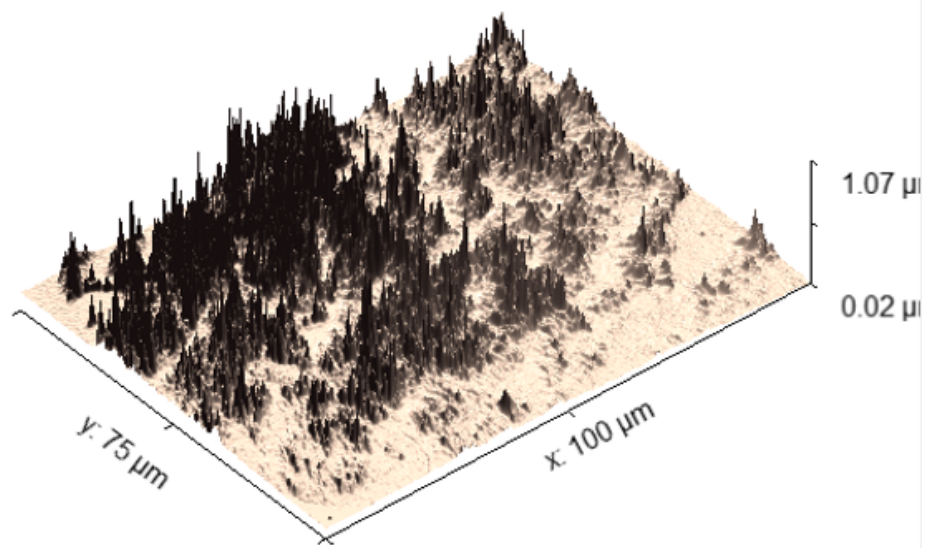

Fig. 1. Surface image after polishing.

The effect of the above factors on the quality of polishing manifests itself in the accumulation of $\mathrm{H}_{2} \mathrm{TiF}_{6}$ и $\mathrm{NO}_{2}$ in the superficial depressions, the size and location of which depends on the laser scanning strategy; this, in its turn, prevents the solution from polishing the surface and worsens its final roughness.

Based on our experiments to study the effect of varying concentrations on the etching rate and the surface quality of Ti6Al4V samples polished with a HF- and nitric-acid solution, we have found that the most optimal solutions are $10 \% \mathrm{HF}+10 \% \mathrm{HNO}_{3}$ and $5 \% \mathrm{HF}+6 \% \mathrm{HNO}_{3}$. The longitudinal and transverse surface roughness was 2.36 and 1.24 times lower, respectively, when polished with the former solution, or 1.50 and 11.34 times lower when polished with the latter solution.

The presented method for polishing Ti6Al4V parts by a hydrofluoric acid solution with added nitric acid can be used for the post-machining of SLM-produced thin-walled geometrically complex parts. The authors recommend using a 10\% HF- and nitric-acid solution as the basic chemical-polishing solution for titanium alloys.

Polishing titanium alloys with $\mathrm{HF}+\mathrm{HNO}_{3}$ solutions can be intensified by circulating the solution or shaking the sample. This removes the accumulated hexafluorotitanic acid, nitrogen dioxide, and water from the surface.

The authors would like to thank the Chemistry Department of the Samara University that help them prepare the etching solutions and carry out the experiments. 


\section{References}

1. Rodney Boyer GW., Materials properties handbook: titanium alloys. Materials Park, OH: ASM International; (1994)

2. H.L. Freese, M.G. Volas, J.R., Wood Metallurgy and technological properties of titanium and titanium alloys D.M. Brunette, P. Tengvall, M. Textor, P. Thomsen (Eds.), Titanium in Medicine: Material Science, Surface Science, Engineering, Biological Responses and Medical Applications, Springer Berlin Heidelberg, New York pp. 25-52 (2001)

3. R.A. Vdovin, V.G. Smelov, M.A. Bolotov, N.D. Pronichev, Paths of Improving the Technological Process of Manufacture of GTE Turbine Blades, IOP Conference Series: Materials Science and Engineering, (2016)

4. R.A. Vdovin, V.G. Smelov, Design and optimization of the micro-engine turbine rotor manufacturing using the rapid prototyping technology, IOP Conference Series: Materials Science and Engineering, (2017)

5. A.V. Agapovichev, A.V. Sotov, V.V. Kokareva etc. Investigation of the effect of laser radiation parameters on the structure and mechanical properties of parts obtained bv the SLM technology from // III Russian scientific seminar with international participation "Interdisciplinary Problems in Additive Technologies". P. 7-8 (2017)

6. Seung MiBaek Alexander V.Polyakov Ji HyunMoon Irina P.Semenova Ruslan Z.Valiev Hyoung SeopKim, Effect of surface etching on the tensile behavior of coarse-and ultrafine-grained pure titanium. Materials Science and Engineering: A, Vol. 707, Pages 337-343 (2017)

7. A.A. Golubeva, A.V. Sotov, A.V. Agapovichev et al., Research of the possibility of using an electrical discharge machining metal powder in selective laser melting, IOP Conference Series: Materials Science and Engineering, (2017)

8. A.V. Balaykin, E.A. Nosova, N.V. Galkina, Study of the Ti-5Al-5Mo-5V-1Cr-1Fe titanium alloy grain structure uniformity after bending and annealing, IOP Conference Series: Materials Science and Engineering, (2017)

9. -S.B.F. Lamolle, M.M.M. Rubert, H.J. Haugen, S.P. Lyngstadaas, J.E. Ellingsen, The effect of hydrofluoric acid treatment of titanium surface on nanostructural and chemical changes and the growth of MC3T3-E1 cells Biomaterials, pp. 736-742 (2009)

10. A.V. Balaykin, E.A. Nosova, N.V. Galkina, Research of Residual Stress after Deformation and Annealing of a Titanium Alloy Ti-5Al-5Mo-5V-1Cr-1Fe Billets // IOP Conference Series: Materials Science and Engineering, Vol. 142. Issue 1. (2016).

11. C. Grosskreutz, D.K. Benson, The effects of the surface on the mechanical properties of metals J.J. Burke, N.L. Reed, V. Weiss (Eds.), Surface and Interfaces II, Syracuse Univ. Press, New York pp. 61-94.C (1968),. Grosskreutz, D.K. Benson The effects of the surface on the mechanical properties of metals J.J. Burke, N.L. Reed, V. Weiss (Eds.), Surface and Interfaces II, Syracuse Univ. Press, New York pp. 61-94 (1968),

12. C. Cassinelli, M. Morra, G. Bruzzone, A. Carpi, Di Santi G, R. Giardino, et al., Surface chemistry effects of topographic modification of titanium dental implant surfaces: 2. In vitro experiments. Int J Oral Maxillofac Implants 18(1): 46-52 (2003)

13. S.B.F. Lamolle, M.M.M. Rubert, H.J. Haugen, S.P. Lyngstadaas, J.E. Ellingsen, The effect of hydrofluoric acid treatment of titanium surface on nanostructural and chemical changes and the growth of MC3T3-E1 cells Biomaterials, pp. 736-742(2009) 
14. G.V. Smirnov, N.D. Pronichev, M.V. Nekhoroshev, V.I. Bogdanovich, Experimental and theoretical study of the hydriding behaviour in the pulse ecm of titanium alloys // IOP Conference Series: Materials Science and Engineering, Vol. 177. Issue 1. (2017)

15. V.G. Smelov, A.V. Sotov, A.V. Agapovichev etc., Investigation of the structure and mechanical properties of the samples fabricated by selective laser melting of TI powder // International Seminar on Interdisciplinary Problems in Additive Technologies. P. 29 (2017) 